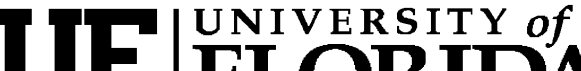 FLORIDA \\ IFAS Extension
}

\section{Licensing of Demonstration and Research Pesticide Applicators in Florida ${ }^{1}$}

Frederick M. Fishel ${ }^{2}$

This document explains the licensing and regulation of persons who apply pesticides for the purpose of conducting demonstration and research activities in Florida, as regulated by the Florida Pesticide Law (Chapter 487), and administered by the Florida Department of Consumer Services.

\section{Demonstration and Research Pest Control}

No license is necessary for those who use or supervise the use of non-restricted use pesticides. The Demonstration and Research Pest Control category is applicable to the following: 1) individuals who publicly demonstrate or supervise the demonstration of the proper use and application techniques of restricted use pesticides or other pesticides requiring licensure. Such individuals may include but are not limited to Extension specialists, county agents, commercial industry representatives, and other individuals who demonstrate pesticide handling procedures used in public programs; and 2) individuals who conduct or supervise field research that utilizes restricted use pesticides or other pesticides requiring licensure. Licensure in this category authorizes pesticide demonstration and research only in accordance with other categories in which licensure is held. For example, a University of Florida IFAS Extension Specialist who applies restricted use pesticides to turfgrass plots as part of a research program at one of the Research and Education Centers would hold the Ornamental and Turf Pest Control Category license in addition to the Demonstration and Research Pest Control Category license. According to internal policy, University of Florida/IFAS employees who handle any restricted use, experimental, or toxicity category I pesticides must be either:

- A certified and licensed pesticide; or

- Working under the direct supervision of a certified and licensed pesticide applicator.

\section{Category Certification Standards}

Applicators seeking a license in this category must demonstrate practical knowledge of:

1. This document is PI-129, one of a series of the Pesticide Information Office, Florida Cooperative Extension Service, Institute of Food and Agricultural Sciences, University of Florida. Original publication date July 2006. Visit the EDIS Web Site at http://edis.ifas.ufl.edu.

2. Frederick M. Fishel, associate professor, Agronomy Department, and Director, Pesticide Information Office; Florida Cooperative Extension Service, Institute of Food and Agricultural Sciences, University of Florida, Gainesville, FL 32611.

The use of trade names in this publication is solely for the purpose of providing specific information. UF/IFAS does not guarantee or warranty the products named, and references to them in this publication does not signify our approval to the exclusion of other products of suitable composition. Use pesticides safely. Read and follow directions on the manufacturer's label.

The Institute of Food and Agricultural Sciences (IFAS) is an Equal Opportunity Institution authorized to provide research, educational information and other services only to individuals and institutions that function with non-discrimination with respect to race, creed, color, religion, age, disability, sex, sexual orientation, marital status, national origin, political opinions or affiliations. U.S. Department of Agriculture, Cooperative Extension Service, University of Florida, IFAS, Florida A. \& M. University Cooperative Extension Program, and Boards of County Commissioners Cooperating. Larry Arrington, Dean 
- Pesticide compatibility, $\mathrm{pH}$, and solubility;

- Proper pesticide use and handling;

- Equipment types and calibration conversions for small plots;

- Principles of integrated pest management;

- Pesticide resistance;

- Safety procedures for pesticide transport, storage, and disposal;

- Interpretation of Material Safety Data Sheets (MSDS) for pesticide products;

- Environmental effects of pesticide use;

- Laws and regulations governing pesticide use and experimental use;

- Biotechnology as it relates to pest control; and

- Liability associated with pesticide use.

\section{License classification}

Certified Demonstration and Research pest control applicators may be licensed as either public applicators or commercial applicators. These are the major differences:

- A public applicator is a licensed applicator employed by a public or governmental agency. The license is only valid when performing work for the public or governmental agency. The public applicator fee for a four-year license is $\$ 60$.

- A commercial applicator is a licensed applicator who is licensed to apply restricted-use pesticides on any property provided they are certified in the category for which the applications are made. A commercial applicator is usually a contract applicator. The commercial applicator fee for a four-year license is $\$ 160$.

\section{Examinations}

Persons must successfully complete three examinations before they can apply to the Department for a license. These examinations are a
Core examination, the Demonstration and Research Pest Control category examination, and the appropriate category(ies) exam(s). The Core examination may be taken at any University of Florida IFAS County Extension Office. The Demonstration and Research Pest Control examination may be taken at a University of Florida IFAS County Extension Office that offers category examinations. No special qualifications must be met to take the examination. There is no fee to take the examinations.

\section{Study materials}

Manuals and study materials for Core and Demonstration and Research Pest Control applicators who will be taking exams may be obtained from the UF/IFAS Extension Bookstore by calling 1-800-226-1764 or on-line at http://www.ifasbooks.ufl.edu/merchant $2 /$. The content of the Core exam is based upon the manual, Applying Pesticides Correctly (Figure 1). The content of the Demonstration and Research Pest Control exam is based upon the manual, Demonstration and Research Pest Control (Figure 2). Sample labels may be obtained from suppliers of pesticide products.

\section{Recertification}

Applicators must recertify every four years. To recertify, applicators may take the examinations again or attend training and obtain 4 continuing education units (CEUs) approved for the Demonstration and Research Pest Control category and the appropriate number of CEUs for the additional category(ies). Core CEUs cant be used to meet the required category CEUs. No substitutions of other types of CEUs are allowed. Opportunities to earn CEUs may be found at http://www.flaes.org/.

\section{Restricted use pesticides applied in Florida}

A complete listing of all restricted use pesticides in Florida may be viewed at: http://edis.ifas.ufl.edu/PI073. The list provides a cross-reference of common active ingredients along with examples of brand names, and the criteria for the restricted classification. 


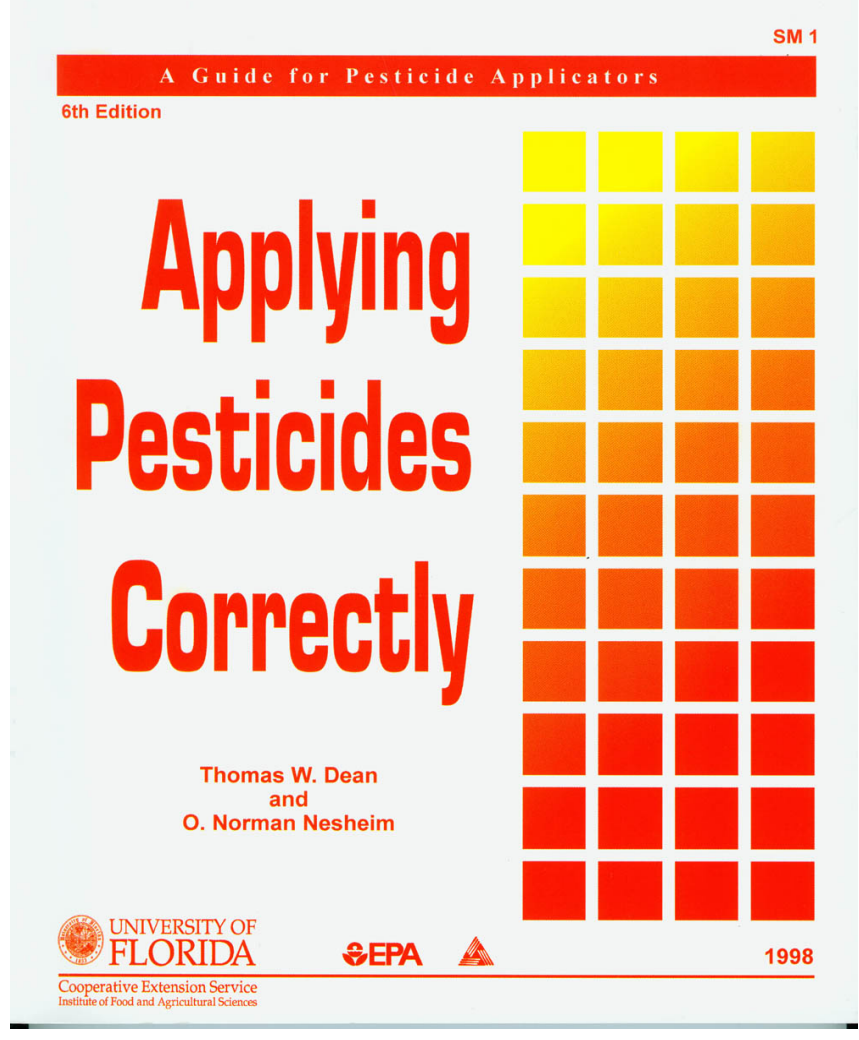

Figure 1. Applying Pesticides Correctly, SM-1.

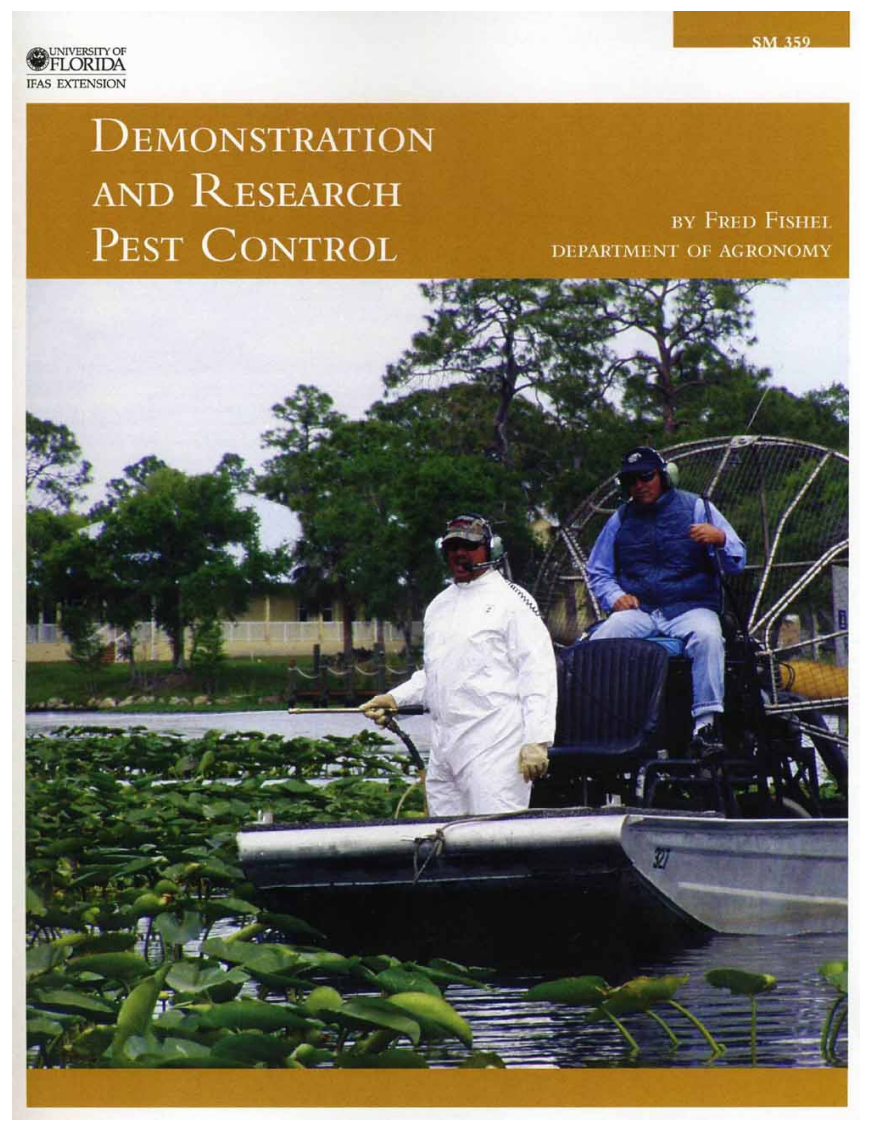

Figure 2. Demonstration and Research Pest Control, SM-359.

\section{Additional information}

Fishel, F.M. 2005. Restricted use pesticides. UF/IFAS EDIS Fact Sheet PI-36, http://edis.ifas.ufl.edu/PI073. (accessed June 28, 2006)

Fishel, F.M. 2005. Experimental-use permits. UF/IFAS EDIS Fact Sheet PI-56, http://edis.ifas.ufl.edu/PI093 (accessed June 28, 2006)

Florida Department of Agriculture and Consumer Services Bureau of Compliance Monitoring, Pesticide Licensing Section, 3125 Conner Drive, Bldg. 8, L-29, Tallahassee, FL 32399-1650, Phone: 850-488-3314, http://www.flaes.org//complimonitoring/index.html (accessed June 20, 2006).

Florida Statutes, Chapter 487. Florida Pesticide Law.

http://www.leg.state.fl.us/statutes/ index.cfm?App_mode=Display_Statute $\& U R L=C h 04$ 87/ch0487.htm

University of Florida/IFAS Pesticide Information Office, P.O. Box 110710, Bldg. 164, Gainesville, FL 32611-0710, Phone: 352-392-4721, http://pested.ifas.ufl.edu/ (accessed June 20, 2006). 